\title{
The role of fire frequency and severity on the regeneration of Mediterranean serotinous pines under different environmental conditions
}

\author{
Víctor Fernández-García ${ }^{\mathrm{a}, *}$, Peter Z. Fulé ${ }^{\mathrm{b}}$, Elena Marcos ${ }^{\mathrm{a}}$, Leonor Calvo ${ }^{\mathrm{a}}$ \\ a Area of Ecology, Department of Biodiversity and Environmental Management, Faculty of Biological and Environmental Sciences, Universidad de León, 24071 León, Spain \\ ${ }^{\mathrm{b}}$ School of Forestry, Northern Arizona University, 86011 Flagstaff, AZ, United States
}

\section{ARTICLE INFO}

\section{Keywords:}

Pinus pinaster

Pinus halepensis

Fire regime

Seedling recruitment

Seedling growth

Competition

\begin{abstract}
A B S T R A C T
Fire frequency and burn severity may increase in pine forests in the Mediterranean Basin under the warmer and drier climate projected for this region. Our study aims to evaluate the role of fire frequency and burn severity in the post-fire recruitment and development of Mediterranean serotinous pines under different environmental conditions. Two pine forests representing contrasting climatic conditions and soil types that support serotinous pines in the Iberian Peninsula and affected by large wildfires in summer 2012, were selected. In these two study sites, we determined the number of wildfires between 1978 and 2012 and the burn severity of the last fire (2012 at both sites) through the dNBR spectral index. Three and four years after the wildfires, we sampled the density, cover and height of pine seedlings and the cover of woody understory species in $12961 \mathrm{~m}^{2}$ plots. The results indicated that the density and cover of pine seedlings was low after two fires combined with high severities, as well as after three fires, regardless of burn severity. Seedling recruitment after three fires was particularly threatened in the most arid study site $\left(0.01\right.$ seedlings $\left.\mathrm{m}^{-2}\right)$, resulting in low seedling cover $(0.01 \%)$. Seedling height decreased with fire frequency in both study sites, and with burn severity owing to fire-induced shifts in soil fertility and microclimatic conditions. There was a significant negative effect of the cover of woody understory species on the recruitment and cover of pine seedlings. Our results suggest that the effects of increasing fire frequency and severity on pine regeneration may be aggravated under arid conditions. Additionally, this study encourages forest managers to avoid the occurrence of frequent crown fires in order to prevent the loss of serotinous pine forest, and provides useful information to predict the scenarios in which post-fire restoration actions would be helpful.
\end{abstract}

\section{Introduction}

Fire plays a critical role in many ecosystems worldwide (Pausas \& Vallejo, 1999), particularly in the Mediterranean Basin, determining the distribution, composition and structure of vegetation, and acting as a selective force for plant traits (Keeley et al., 2012). The vegetation in Mediterranean ecosystems recovers after fires mainly from endogenous sources (Moreno \& Oechel, 2012). In general, plant species in this region can regenerate after wildfires by resprouting from tissues that survive fire (resprouters), by seedling recruitment (obligate seeders), or by the combination of both mechanisms (facultatives) (Calvo et al., 1998, 2002a, 2002b; Pausas \& Vallejo, 1999; Pausas \& Keeley, 2014).

All the pine species naturally distributed across the Mediterranean Basin are obligate seeders (Tapias et al., 2001; Pausas et al., 2008). Pinus pinaster Ait. and Pinus halepensis Mill. are two of the most widespread species (Richardson, 2000; Tapias et al., 2004). Both pines are highly flammable (Fernandes et al., 2008), and dominate forest ecosystems with a continuous and high (up to $1.5 \mathrm{~m}$ ) woody understory layer. This fuel profile facilitates the occurrence of crown fires that cause a high mortality rate (Daskalakou \& Thanos, 2004; Fernandes et al., 2008; Calvo et al., 2008). As an adaption to this fire regime (Keeley et al., 2011; He et al., 2012; Hernández-Serrano et al., 2013), P. halepensis and most $P$. pinaster populations are able to store seeds in closed cones (serotinous cones) within the canopy for longer than one reproductive cycle (Tapias et al., 2001, 2004; Daskalakou \& Thanos, 2004; Moya et al., 2018). The seeds in serotinous cones are protected from fire and massively released after the disturbance, finding proper conditions for germination, seedling establishment and growth (Calvo et al., 2008; Moya et al., 2008; Keeley et al., 2011). In general, this mechanism ensures the regeneration of $P$. pinaster and $P$. halepensis forests after a fairly wide range of burn severities, but many studies have indicated that very high burn severity can cause significant seed mortality

\footnotetext{
* Corresponding author.

Email address: vferg@unileon.es (V. Fernández-García)
} 
(Fernandes et al., 2008; Fernández et al., 2008; Maia et al., 2012; García-Llamas et al., 2019a).

Another characteristic of the fire regime in Mediterranean pine ecosystems is the repeated occurrence of fires at short intervals, with $P$. pinaster and $P$. halepensis being the tree species most affected by fire in the Iberian Peninsula (ADCIF, 2012; ICFN, 2015). Simulation studies have indicated that intermediate fire return intervals (40-100years) are optimal for maintaining Mediterranean pine forests (Pausas, 1999). In fact, the reproductive precocity of $P$. pinaster (4-10years) and $P$. halepensis (4-8 years) is considered an adaptation to a relatively frequent fire regime (Tapias et al., 2004; González-de-Vega et al., 2016 Moya et al., 2018). However, when fire frequency is out of the natural range, regeneration may be endangered because these pines need at least 15 or 20 years to develop a fully productive canopy seed bank (Pausas et al., 2008).

Thus, previous research indicated that fire frequency and burn severity directly affect pine regeneration, but additional indirect effects may be expected through changes in the abundance and composition of the woody understory community (Pausas, 1999; Pausas \& Keeley, 2014; Fernández-García et al., 2017). Frequent fires (fire intervals $\leq 20$ years) may facilitate the development of woody understory species (Pausas, 1999; Fernández-García et al., 2018a), which compete with pines for light ( $P$. pinaster and $P$. halepensis seedlings are heliophilous; Richardson, 2000), space, and nutrients (De las Heras et al., 2002; Calvo et al., 2005, 2008, 2013; Taboada et al., 2017). Additionally, previous studies have indicated that high burn severity can favor the recovery of seeders at the expense of resprouters (Pausas \& Keeley, 2014). This potential change in understory community composition can also interact with pine regeneration, as the competition exerted by woody species on pines can vary depending on the vegetation functional type (Taboada et al., 2017).

Although Mediterranean serotinous pine forests are adapted to certain fire regimes (Pausas et al., 2008), rural abandonment in the European countries of the Mediterranean Basin has led to an increase in fuel loads and continuity (Lindner et al., 2008; Moreira et al., 2012; Doblas-Miranda et al., 2017; García-Llamas et al., 2019a). Fuel accumulation coupled with an expected warmer and drier climate, particularly during summer (Giorgi \& Lionello, 2008), could lead to increases in fire frequency (Vázquez et al., 2015) and burn severity that can hinder pine regeneration (Fernandes et al., 2008; Flatley \& Fulé, 2016). Knowledge of the effects of fire frequency and severity on pines is crucial for land-managers to predict post-fire regeneration and develop post-fire restoration strategies aimed at maintaining the forest ecosystem (Moreira et al., 2012; García-Llamas et al., 2019a). Previous studies have analyzed separately the effects of fire frequency (Eugenio \& Lloret, 2004; Baeza et al., 2007) and burn severity (Fernández et al., 2008; Moya et al., 2018) on the regeneration of Mediterranean serotinous pines. However, the pine regeneration results are inconsistent, particularly in relation to burn severity (Pausas et al., 2003; Vega et al., 2008; González-de-Vega et al., 2016). Therefore, the study of seedling recruitment and development of serotinous pines after different frequencies and severities in different environmental conditions (e.g. soil and climate) may help to clarify the situation. Additionally, we have not found any studies analyzing the interacting effects of fire frequency and burn severity on seedling recruitment and development. Such an approach may provide realistic insights into the post-fire regeneration capacity of the ecosystem, since both variables overlap under natural conditions (Fernández-García et al., 2018a).

The objective of the present study is to analyze the role of fire frequency and burn severity in post-fire regeneration of serotinous pines in Mediterranean ecosystems over the medium term (three and four years) after fire. In particular, we aim to answer the following questions: (i) Does the combination of frequent fires and high severities constrain the post-fire recruitment (density) and development (cover and height) of pine seedlings? (ii) Does competition between woody understory species and pine regeneration vary depending on fire fre- quency and burn severity? (iii) Does the impact of fire frequency and burn severity on pine regeneration vary depending on the environmental conditions? According to previous research, we would expect a decrease in pine seedling recruitment after frequent fires (Eugenio \& Lloret, 2004; Baeza et al., 2007; Taboada et al., 2017), as well as in high severity patches (Fernandes \& Rigolot, 2007; González-de-Vega et al., 2016). Thus, natural regeneration of pines would be particularly limited when combining high fire frequency and extreme severity situations. Additionally, we hypothesize that increases in fire frequency and burn severity would negatively affect the development of pines (cover and height) through changes in seedling growth conditioning factors, such as microclimatic conditions (Pausas et al., 2004a) and soil properties (Fernández-García et al. 2019). We also expect competition between woody understory species and pine regeneration (Calvo et al., 2005, 2008) to be mediated by fire frequency and severity, as changes in these fire regime attributes entail changes in community structure and composition (Pausas \& Keeley, 2014; Taboada et al., 2017). Finally, we expect the impact of frequent and severe fires to be stronger in warmer and drier areas (Flatley \& Fulé, 2016), because droughts constrain seedling establishment and growth (Padilla \& Pugnaire, 2007; Rodríguez-García et al., 2011; Calvo et al., 2013; Lucas-Borja, 2016).

\section{Material and methods}

\subsection{Study sites}

We selected two study sites burned in summer 2012, representing contrasting climatic conditions and soil types that support serotinous pine forests in the Iberian Peninsula. The first site is Sierra del Teleno $\left(42^{\circ} 15^{\prime} \mathrm{N} 6^{\circ} 11^{\prime} \mathrm{W}\right)$, dominated by $P$. pinaster ecosystems, with two months of summer drought and acidic soils. The second site is Cortes de Pallás $\left(39^{\circ} 18^{\prime} \mathrm{N} 0^{\circ} 54^{\prime} \mathrm{W}\right)$, dominated by $P$. halepensis ecosystems, with four months of summer drought and calcareous soils (Figs. 1, 2; Table 1).

The Sierra del Teleno wildfire was a high-intensity crown fire that burned $119 \mathrm{~km}^{2}$ in the northwestern Iberian Peninsula (León province, Spain). The study site is located in a mountain range with a heterogeneous fire history (large wildfires also occurred in 1978, 1991 and 1998, among others) (Fig. 2). Sierra del Teleno is dominated by natural $P$. pinaster forests $\left(103 \mathrm{~km}^{2}\right)$ with $97 \%$ serotinous trees (Tapias et al., 2004). Tree density in old stands (no wildfires recorded since 1978) in Sierra del Teleno is 765 plantsha $^{-1}$. The shrubby understorey community is mostly comprised of Pterospartum tridentatum (L.) Willk., Halimium lasianthum (Lam.) Spach and Erica australis L. The climate is temperate with dry temperate summers (AEMET-IM, 2011), averaging two months of summer drought (transition between Mediterranean and Oceanic climates). Soils are siliceous, with sandy loam texture and relatively poor in nutrients ( $4 \mu \mathrm{g}$ available $\mathrm{Pg}^{-1}$ dry soil and $2 \mathrm{mg}$ total $\mathrm{Ng}^{-1}$ dry soil; Fernández-García et al., 2019). Pine mortality caused by the wildfires was almost total (Fig. 1) and salvage logging was conducted following the fires. After the 2012 wildfire, only unmerchantable trees ( $<10 \mathrm{~cm}$ diameter) were left on the site (Taboada et al., 2018).

The Cortes de Pallás wildfire burned an area of $297 \mathrm{~km}^{2}$ in the eastern Iberian Peninsula (Valencia province, Spain). Part of the area had been burned by previous wildfires in 1978, 1991 and 1994. The Cortes de Pallás wildfire burned $66 \mathrm{~km}^{2}$ occupied by $P$. halepensis natural forests $(100 \%$ of serotinous trees, Tapias et al., 2001; Hernández-Serrano et al., 2013), with localized presence of $P$. pinaster. Tree density in stands unburned since 1978 in Cortes de Pallás was 283 plants ha $^{-1}$. The understory of these fire-prone pine ecosystems was dominated by Ulex parviflorus Pourr., Quercus coccifera L. and Rosmarinus officinalis $\mathrm{L}$. The climate is temperate, with warm dry summers (AEMET-IM, 2011) resulting in four months of summer drought (typical Mediterranean conditions). Soils are calcareous, with loamy sand or 

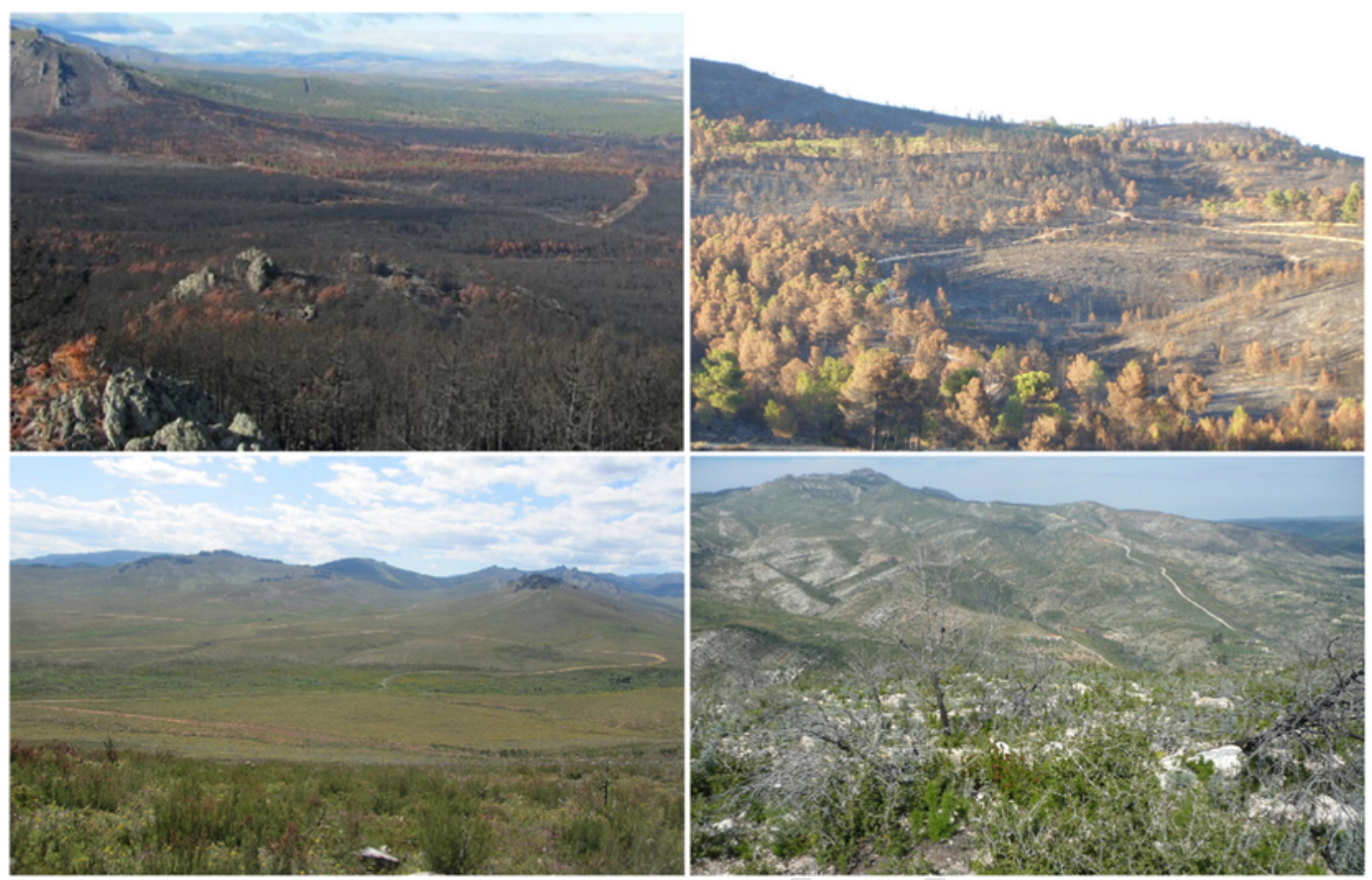

Fig. 1. Photos of the study sites (Sierra del Teleno on the left and Cortes de Pallás on the right) immediately after the fire (top) and three years after the fire (bottom).

Table 1

Characteristics of the study sites.

\begin{tabular}{|c|c|c|}
\hline & Sierra del Teleno wildfire & $\begin{array}{l}\text { Cortes de Pallás } \\
\text { wildfire }\end{array}$ \\
\hline Fire alarm date & August 19th, 2012 & June 28th, 2012 \\
\hline Wildfire size $\left(\mathrm{km}^{2}\right)$ & 118.91 & 297.52 \\
\hline $\begin{array}{l}\text { Previous large } \\
\text { wildfires }\end{array}$ & 1978, 1991, 1998 & 1978, 1991, 1994 \\
\hline $\begin{array}{l}\text { Dominant pine } \\
\text { species }\end{array}$ & P. pinaster & P. halepensis \\
\hline $\begin{array}{l}\text { Pine ecosystem } \\
\text { burned }\left(\mathrm{km}^{2}\right)\end{array}$ & 102.65 & 65.69 \\
\hline Elevation (m) & $836-1493$ & $120-942$ \\
\hline Aspect & $\mathrm{N}, \mathrm{S}, \mathrm{W}, \mathrm{E}$ & $\mathrm{N}, \mathrm{S}, \mathrm{W}, \mathrm{E}$ \\
\hline $\begin{array}{l}{ }^{1} \text { Mean annual } \\
\text { precipitation } \\
\text { (mm) }\end{array}$ & $600-800$ & $400-600$ \\
\hline $\begin{array}{l}{ }^{1} \text { Mean annual } \\
\text { temperature }\left({ }^{\circ} \mathrm{C}\right)\end{array}$ & $8-11$ & $13-17$ \\
\hline${ }^{2}$ Lithology & $\begin{array}{l}\text { Quartzite, conglomerate, } \\
\text { sandstone, sand, slate, silt }\end{array}$ & $\begin{array}{l}\text { Limestone, dolomite, } \\
\text { sandstone, marl }\end{array}$ \\
\hline $\begin{array}{l}{ }^{3} \text { Soil WRB } \\
\text { classification }\end{array}$ & $\begin{array}{l}\text { Haplic Umbrisol, Dystric } \\
\text { Regosol }\end{array}$ & $\begin{array}{l}\text { Haplic Calcisol, } \\
\text { Calcari-lithic Leptosol }\end{array}$ \\
\hline${ }^{4}$ Soil pH & $4.86 \pm 0.14$ & $8.14 \pm 0.06$ \\
\hline
\end{tabular}

1 Precipitation and temperature were obtained from Ninyerola et al. (2005).

2 Lithologies were determined according to the geological map of Spain (GEODE, 2019).

3 World Reference Base for Soil Resources classification according to Jones et al. (2005).

4 A suspension of soil:deionized water was used to determine $\mathrm{pH}(1: 2.5, \mathrm{w} / \mathrm{v})$.

sandy loam texture, and higher nutrient concentrations than soils in Sierra del Teleno $\left(12 \mu \mathrm{g}\right.$ available $\mathrm{P} \mathrm{g}^{-1}$ dry soil and $3 \mathrm{mg}$ total $\mathrm{Ng}^{-1}$ dry soil; Fernández-García et al., 2019). The Cortes de Pallás wildfire was, in general, a stand replacing fire in the areas dominated by pine forests (Fig. 1), and salvage logging was conducted in a small portion of the affected area.

\subsection{Fire frequency and burn severity}

We characterized the fire frequency (number of wildfires between 1978 and 2012) and burn severity of the last wildfire (wildfires oc- curred in 2012) in the two study sites. The fire perimeters of the wildfires occurred in Sierra del Teleno since 1978 were mapped using Landsat imagery false colour composites and aerial orthophotography, and validated with official information according to Fernández-García et al. (2018a). In Cortes de Pallás, official fire perimeters were available for the entire study period (Alloza et al., 2012). We obtained a fire frequency map (1978-2012) for the two study sites by overlaying the fire scars.

Burn severity was obtained as a continuous variable by calculating the differenced Normalized Burn Ratio (dNBR) (Key, 2006). This index is a standard burn severity metric and has shown a high accuracy for assessing burn severity in forest ecosystems within the Iberian Peninsula (Fernández-García et al., 2018a, 2018b; García-Llamas et al., 2019b). Landsat 7 ETM + scenes from September 20th, 2011 (pre-fire) and from September 6th, 2012 (post-fire) were used to calculate the dNBR in the Sierra del Teleno wildfire, and Landsat 7 ETM + scenes from August 22nd, 2011 (pre-fire) and from August 25th, 2012 (post-fire) in the Cortes de Pallás wildfire. Images were atmospherically corrected using the FLAASH module (Perkins et al., 2012) and topographically corrected by applying the C-correction (Teillet et al., 1982) (see Fernández-García et al., 2018b for a detailed description on the imagery pre-processing). Then, dNBR was calculated using the following equations:

$\operatorname{NBR}=\left(\rho_{4}-\rho_{7}\right) /\left(\rho_{4}+\rho_{7}\right)$;

$\mathrm{dNBR}=\left(\mathrm{NBR}_{\text {pre }}-\mathrm{NBR}_{\text {post }}\right)--$ offset

where NBR is the Normalized Burn Ratio, calculated in the pre-fire situation $\left(\mathrm{NBR}_{\mathrm{pre}}\right)$ and in the post-fire situation $\left(\mathrm{NBR}_{\mathrm{post}}\right), \rho$ is the land surface reflectance in percentage for each specific Landsat 7ETM + band, dNBR is the differenced Normalized Burn Ratio ranging from -2 to 2, and offset is the average index value from pixels in homogeneous and unchanged areas near the fire scar.

\subsection{Field sampling}

In each study site, we focused the field sampling in a frame of 3000 ha established in areas dominated by pine ecosystems, with three 

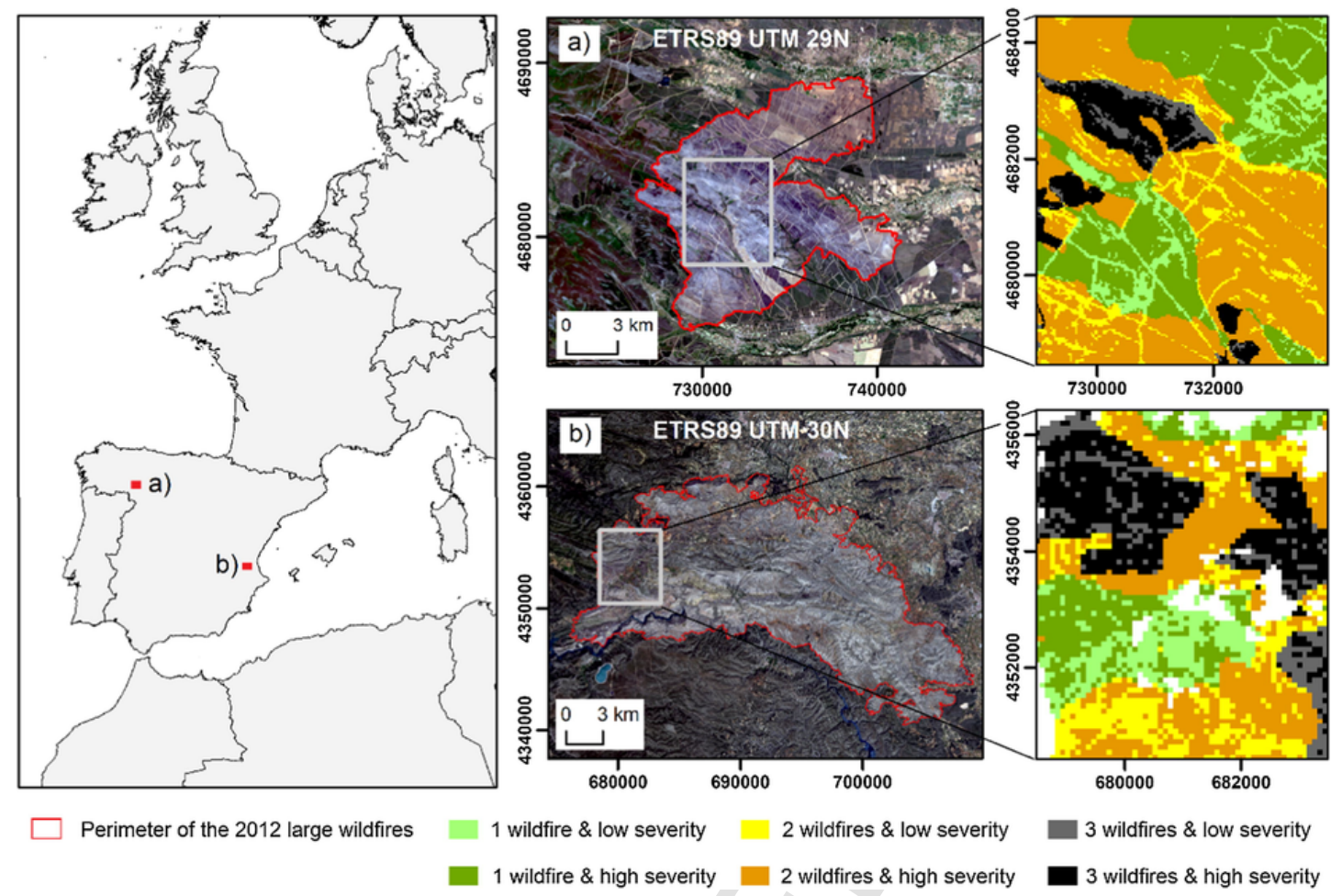

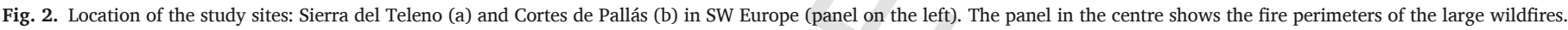

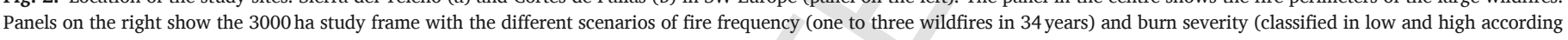
to the dNBR index).

fire frequency scenarios and heterogeneous burn severity (Fig. 2). Aiming to design a field sampling representative of the different fire frequency and severity situations, we developed a fire frequency-severity map for each study site (Fig. 2). In these maps we obtained six frequency-severity categories by combining the fire frequency (one to three fires) and burn severity classified into low and high (using the dNBR value 550 as threshold, which can be considered moderate burn severity; Fernández-García et al., 2018a, 2018b, 2019). We distributed $30 \mathrm{~m} * 30 \mathrm{~m}$ field plots (corresponding to the spatial resolution of Landsat ETM + reflective bands) proportionally to the area of each frequency-severity category, with a minimum of 30 plots per study site and ensuring that all the fire frequency-severity scenarios were represented. The minimum distance between plots was $200 \mathrm{~m}$. A total of 108 field plots of $30 \mathrm{~m} * 30 \mathrm{~m}$ was established: 78 plots in Sierra del Teleno and 30 in Cortes de Pallás. In each $30 \mathrm{~m} * 30 \mathrm{~m}$ plot, we located three $2 \mathrm{~m} * 2 \mathrm{~m}$ subplots, divided into four $1 \mathrm{~m} * 1 \mathrm{~m}$ quadrats. Plot and subplot centres were fixed in field for successive monitoring and geo-referenced with high precision GPS (RMSE $\left.E_{X, Y}<0.5 \mathrm{~m}\right)$.

To analyze the post-fire regeneration of pines over the medium term after the fire, we surveyed the $1296(1 \mathrm{~m} * 1 \mathrm{~m})$ quadrats distributed in the two wildfires in May-June 2015 (three years after fire), and again in May-June 2016 (four years after fire). In each quadrat (i) we measured the number of pine seedlings, (ii) we visually estimated the percentage cover of pine seedlings, and (iii) we calculated the mean height of pine seedlings by averaging the height of 10 randomly selected individuals. Additionally, to evaluate the potential competition effects of woody understory species on pine recruitment and development, we estimated the percent cover of each woody species in each $1 \mathrm{~m} * 1 \mathrm{~m}$ quadrat, and calculated the global cover of woody understory species as the sum of the individual cover of all species.

\subsection{Data analysis}

To analyze the effects of time since the wildfire (three and four years), fire frequency (number of wildfires between 1978 and 2012), burn severity (continuous value of the dNBR spectral index), and the competition of woody understory species (percentage cover) on pine regeneration, we fit generalized linear mixed models (GLMMs) for each study site. We used penalized quasi-likelihood (glmmPQL function) to account for overdispersion. We studied three response variables: number of pine seedlings (density), percentage cover of pine seedlings, and mean height of pine seedlings. The density and cover of pine seedlings were fitted following a quasi-Poisson error distribution using the log link function, whereas a Gaussian error distribution with the identity function was used to model the mean height of pine seedlings. The identities of the $30 \mathrm{~m} * 30 \mathrm{~m}$ and $2 \mathrm{~m} * 2 \mathrm{~m}$ field plots were included in the models as a nested random factor. We retained the interaction terms in the models only when they were significant $(P<0.05)$.

All data analyses were carried out with R (R Core Team, 2017), using the MASS (Venables \& Ripley, 2002) and nlme (Pinheiro et al., 2017) packages.

\section{Results}

All the explanatory variables (time, fire frequency, burn severity and total cover of woody understory species) had significant effects on the recruitment of pine seedlings in $P$. pinaster and $P$. halepensis ecosystems over the medium term after fire (Table 2). Results showed a significant decrease in the number of pine seedlings per $\mathrm{m}^{2}$ in time (from the third to the fourth year) in both Pinus pinaster $(2.25 \pm 0.15$ to $1.77 \pm 0.11$; mean \pm standard error) and Pinus halepensis ecosystems $(2.85 \pm 0.17$ to $2.68 \pm 0.54)$. Focusing on the fire regime attributes, we found that increases in both fire frequency and burn severity had a negative impact on the recruitment of pine seedlings in the $P$. pinaster 
Table 2

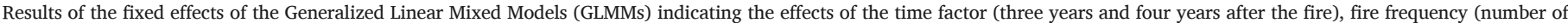

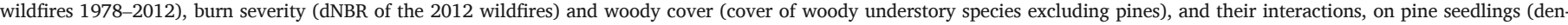

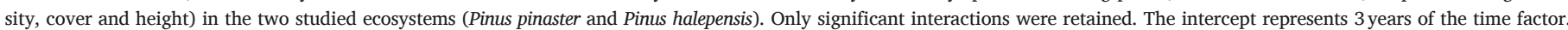
$\mathrm{SE}=$ standard error. Significant $P$-values are in bold face.

\begin{tabular}{|c|c|c|c|c|c|c|c|}
\hline \multirow[t]{2}{*}{ Response variable } & \multirow[t]{2}{*}{ Predictor Variable } & \multicolumn{3}{|c|}{ Pinus pinaster ecosystem } & \multicolumn{3}{|c|}{ Pinus halepensis ecosystem } \\
\hline & & Estimate & SE & $P$ value & Estimate & SE & $P$ value \\
\hline \multirow[t]{9}{*}{ Density of seedlings (pines $/ \mathrm{m}^{2}$ ) } & Intercept & 3.532 & 0.528 & $<0.001$ & 6.101 & 3.007 & 0.043 \\
\hline & Time & -0.189 & 0.043 & $<0.001$ & -0.111 & 0.044 & 0.012 \\
\hline & Frequency & -1.425 & 0.152 & $<0.001$ & -2.489 & 1.934 & 0.209 \\
\hline & Severity & -1.442 & 0.565 & 0.013 & -3.580 & 5.162 & 0.494 \\
\hline & Woody cover & -0.003 & 0.001 & 0.014 & 0.030 & 0.029 & 0.306 \\
\hline & Frequency * Severity & - & - & - & -1.914 & 3.469 & 0.586 \\
\hline & Frequency *Woody cover & - & - & - & -0.031 & 0.028 & 0.274 \\
\hline & Severity * Woody cover & - & - & - & -0.107 & 0.047 & 0.023 \\
\hline & Frequency * Severity* Woody cover & - & - & - & 0.094 & 0.045 & 0.039 \\
\hline \multirow[t]{5}{*}{ Cover of seedlings (\%) } & Intercept & 3.792 & 0.448 & $<0.001$ & 5.595 & 1.335 & $<0.001$ \\
\hline & Time & 0.461 & 0.042 & $<0.001$ & 0.342 & 0.046 & $<0.001$ \\
\hline & Frequency & -1.436 & 0.132 & $<0.001$ & -2.819 & 0.456 & $<0.001$ \\
\hline & Severity & -0.603 & 0.479 & 0.212 & -3.894 & 1.643 & 0.025 \\
\hline & Woody & -0.007 & 0.001 & $<0.001$ & -0.004 & 0.002 & 0.018 \\
\hline \multirow[t]{6}{*}{ Height of seedlings (cm) } & Intercept & 12.055 & 7.248 & 0.097 & 3.646 & 0.287 & $<0.001$ \\
\hline & Time & 8.602 & 0.758 & $<0.001$ & 0.367 & 0.050 & $<0.001$ \\
\hline & Frequency & -4.723 & 1.994 & 0.021 & -0.363 & 0.131 & 0.013 \\
\hline & Severity & 25.055 & 7.983 & 0.003 & -0.540 & 0.380 & 0.173 \\
\hline & Woody cover & 0.054 & 0.057 & 0.341 & 0.002 & 0.002 & 0.254 \\
\hline & Severity*Woody cover & -0.144 & 0.070 & 0.042 & - & - & - \\
\hline
\end{tabular}

ecosystem (Table 2; Fig. 3). Similarly, there was a clear negative effect of the cover of woody understory species on seedling recruitment (Table 2; Fig. 4). In the case of $P$. halepensis, the effects of fire frequency, severity and competition on the density of pine seedlings showed similar trends (Figs. 3 and 4). However, the triple interaction found in the $P$. halepensis ecosystem means that the strong effect of each single predictor on pine recruitment obscured the effect of the other two in the less favourable scenarios (two or three wildfires, high severity and/or high cover of woody species), because pine density had already decreased to very low values. In both ecosystems, the lowest pine seedling density occurred in areas affected by two wildfires combined with high severity $\left(<0.40\right.$ seedlings $\left.\mathrm{m}^{-2}\right)$, and in the areas affected by three wildfires, regardless of burn severity and cover of woody species $(0.34 \pm 0.07$ seedlings $\mathrm{m}^{-2}$ in the $P$. pinaster ecosystem; $0.01 \pm 0.01$ seedlings $\mathrm{m}^{-2}$ in the $P$. halepensis ecosystem) (Figs. 3 and 4).

The percent cover of pine seedlings increased from the third to the fourth year after the fire (Table 2) $(4.30 \pm 0.26$ to $6.05 \pm 0.36$ in the $P$. pinaster ecosystem; $2.45 \pm 0.39$ to $3.41 \pm 0.42$ in the $P$. halepensis ecosystem). However, as with pine density, the cover of pine seedlings significantly decreased with fire frequency in both ecosystems (Fig. 3). Burn severity had significant effects on cover of pine seedlings only in the $P$. halepensis ecosystem, although both forests showed the same pattern (Fig. 3). The cover of pine seedlings significantly decreased with the cover of woody understory species in both ecosystems, especially in the areas affected by one wildfire (Fig. 4). In general, the areas with the lowest cover of pine seedlings corresponded with those with the lowest density of pine seedlings, showing a significant correlation even four years after the fire $\left(\mathrm{R}^{2}=0.45, P<0.01\right.$ in $P$. pinaster; $\mathrm{R}^{2}=0.66$, $P=0.01$ in $P$. halepensis).

The height of pine seedlings significantly increased in time (Table 2) $(22.71 \mathrm{~cm} \pm 0.71$ to $30.24 \mathrm{~cm} \pm 0.93$ in the $P$. pinaster ecosystem; $22.12 \mathrm{~cm} \pm 1.26$ to $33.03 \mathrm{~cm} \pm 1.70$ in the $P$. halepensis ecosystem) and decreased with fire frequency in both ecosystems (Table 2; Fig. 3). In the $P$. pinaster ecosystem, we found a significant interaction effect of burn severity and cover of woody species on the height of pine seedlings (Fig. 4). This result suggests that higher burn severity facilitated the development in height of pine seedlings only when the cover of woody species was not very high. We did not find significant effects of burn severity or cover of woody understory species on seedling height in the P. halepensis ecosystem (Table 2, Figs. 3 and 4).

\section{Discussion}

We found that the post-fire recruitment and development of Mediterranean serotinous pine seedlings is influenced by fire frequency (number of wildfires in 34 years) and severity (dNBR spectral index), as well as by the inter-specific competition with woody species (cover of woody understory species). The influence of these variables on the regeneration of $P$. pinaster and $P$. halepensis can be attributed to effects on: (i) the canopy seed bank existing prior to the fire (Daskalakou \& Thanos, 1996; Fernández et al., 2008), (ii) seed survival and germination (Daskalakou \& Thanos, 2004; Fernandes \& Rigolot, 2007), and (iii) post-fire establishment and dynamics of pine seedlings, which are highly dependent on environmental conditions such as climate (Padilla \& Pugnaire, 2007; Calvo et al., 2008; Fernández et al., 2008; Taboada et al., 2017).

\subsection{Fire frequency effects on pine regeneration}

Our results indicated that increased fire frequency reduced seedling density over the medium term after the fire (three and four years). Previous studies have found decreases in the density of seedlings after frequent fires in both $P$. pinaster (Torres et al., 2016; Taboada et al., 2017) and $P$. halepensis ecosystems (Eugenio et al., 2006; Santana et al., 2010; Arnan et al., 2013). Presumably, community replacement would be expected if two consecutive fires occur in a period shorter than necessary for pines to reach reproductive maturity (4-10years $P$. pinaster, 4-8 years P. halepensis; Tapias et al., 2004, Baeza et al., 2007). However, large decreases in pine recruitment would also be expected when fire intervals are shorter than the time necessary to accumulate a critical seed store for guaranteeing self-replacement (Eugenio \& Lloret, 2004). Several authors have stated that the minimum fire intervals in Mediterranean fire-prone pines are around 15-20 years (Eugenio et al., 2006; Santana et al., 2010), coinciding with the scenarios of two and three wildfires in this study. Additionally, changes in environmental conditions owing to fire frequency may affect the density of pine seedlings. For example, it has been demonstrated that the amount of both light fuel and coarse woody debris on the forest floor, which is lower after 


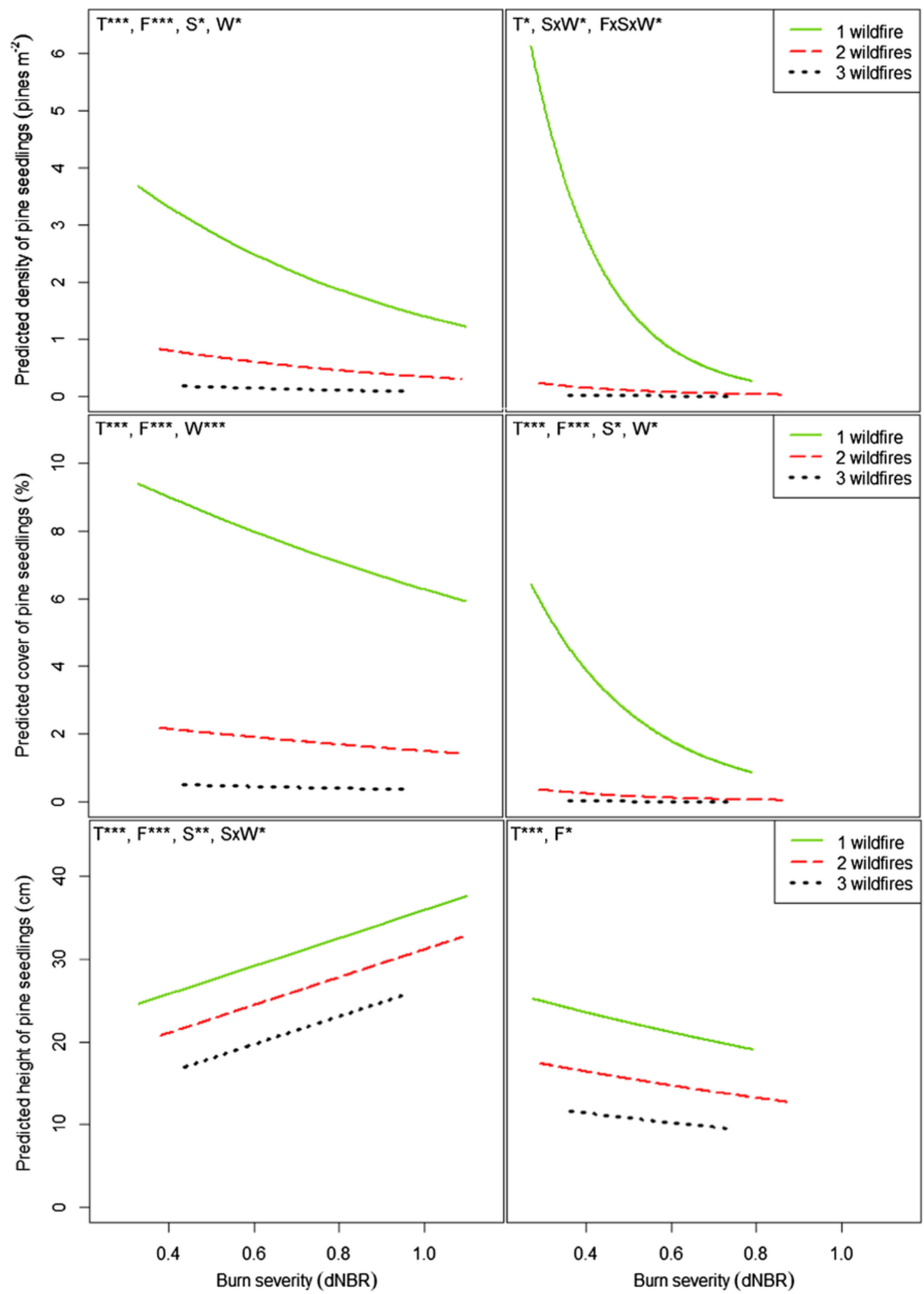

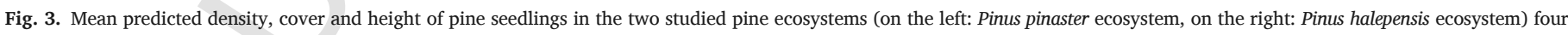

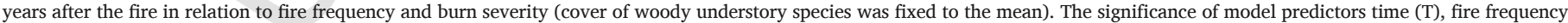
(F), burn severity (S), cover of woody understory species (W) and their interactions are represented as * $(P<0.05)$, ** $(P<0.01)$ and *** $(P<0.001)$.

frequent fires, provide seed protection from predation (Taboada et al., 2018) and appropriate microclimatic conditions for seedling establishment (Pausas et al., 2004a). In this study, we observed that the per- centage of soil covered by plant debris is still higher four years after the fire in the areas burned once than in those affected by two or three wildfires $(17.32 \%, 10.72 \%$ and $7.04 \%$ in the $P$. pinaster ecosystem; 


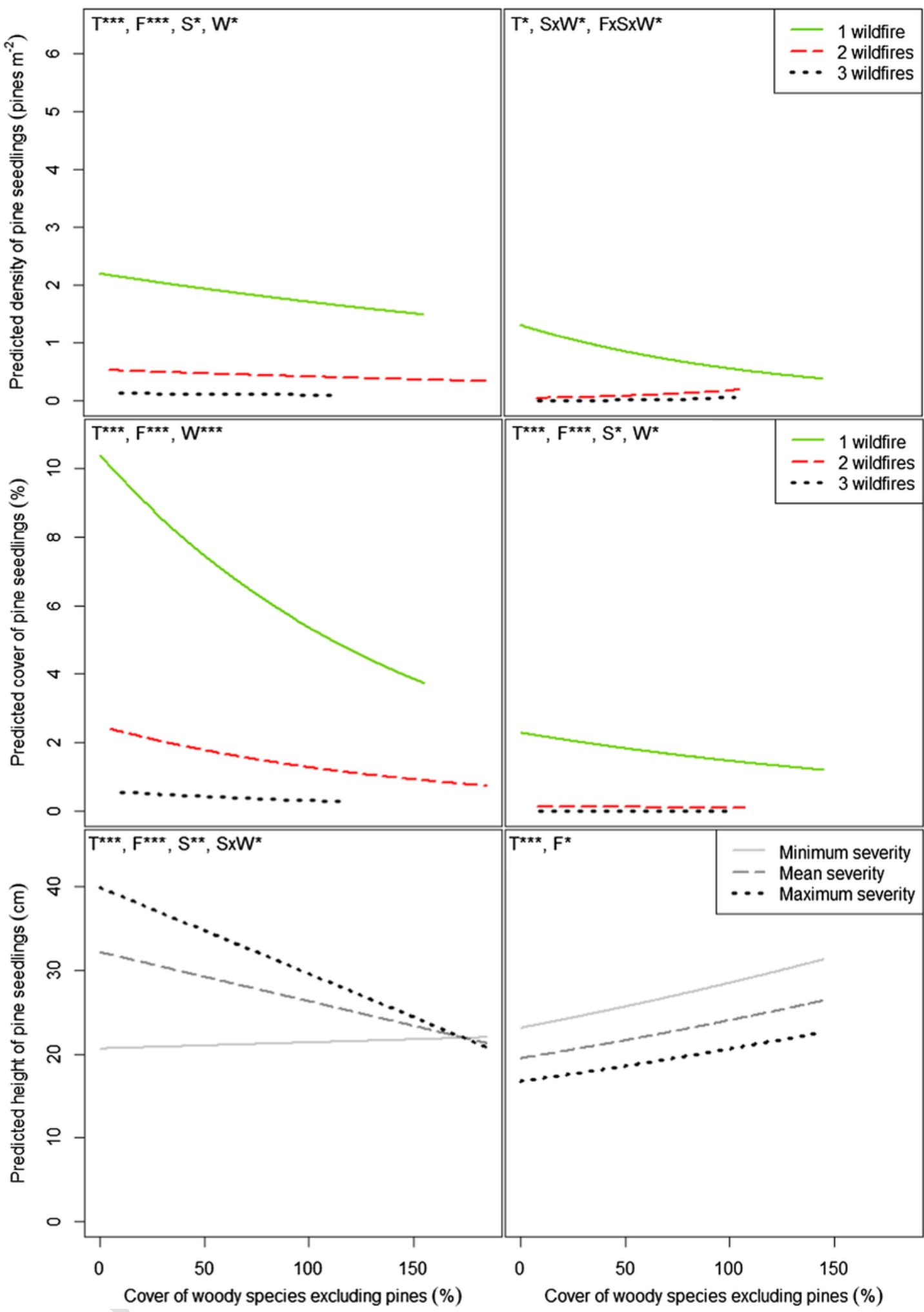

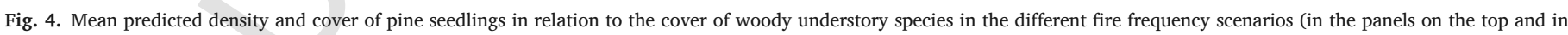

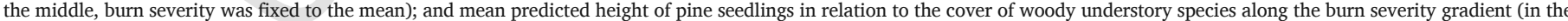

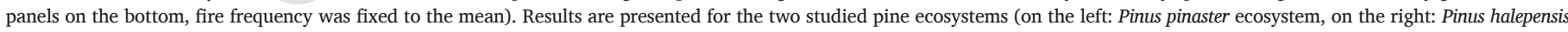

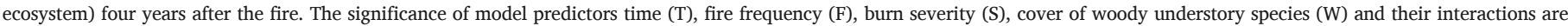
represented as * $(P<0.05), * *(P<0.01)$ and $* * *(P<0.001)$. 
$48.20 \%, 28.92 \%$ and $27.36 \%$ in the $P$. halepensis ecosystem in the areas burned once, twice and three times, respectively). Therefore, the lowest fire frequency provides the best microclimatic conditions for seedling establishment. Fire frequency also showed a significant impact on the variables related to the development of pine seedlings: cover of pine seedlings, which was dependent on the density of pine seedlings ( $\mathrm{R}^{2} \geq 0.45, P<0.054$ years after the fire), and height of pine seedlings. The negative effects of high fire frequencies on the development of seedlings could be explained by the decrease in soil nutrient concentrations after recurrent fires (Eugenio \& Lloret, 2004, Eugenio et al. 2006). In fact, the available $\mathrm{P}$ concentration, which can be a limiting nutrient in forest soils (Binkler \& Fisher, 2013), largely decreased with fire frequency even four years after the fire in our two study sites $(12.60 \mathrm{ppm}$, $5.07 \mathrm{ppm}, 3.07 \mathrm{ppm}$ in the $P$. pinaster ecosystem; $13.77 \mathrm{ppm}, 8.92 \mathrm{ppm}$ and $8.03 \mathrm{ppm}$ in the $P$. halepensis ecosystem in the areas burned once, twice and three times, respectively). The plant debris covering the forest floor, which decreased with fire frequency, is another factor that may be related to the decreased development of pines after two and three fires (Taboada et al., 2018). The plant debris may contribute to the growth of seedlings by reducing water stress (Fernández et al., 2008), increasing protection from adverse climatic conditions, and providing nutrients over the medium term (Taboada et al., 2018).

\subsection{Burn severity effects on pine regeneration}

The other fire regime attribute we studied, burn severity, also decreased the recruitment of pine seedlings, mainly in the single fire occurrence scenarios. Serotinous cones are an extraordinary mechanism to protect seeds from fire, maintaining their viability at temperatures up to $400^{\circ} \mathrm{C}$ for $1 \mathrm{~min}$ (Habrouk et al., 1999; Fernandes \& Rigolot, 2007). However, higher temperatures or longer exposure time cause high mortality rates of seeds encased in serotinous cones as well as total mortality of non-protected seeds (Habrouk et al., 1999; Fernandes \& Rigolot, 2007). Considering that these temperatures are exceeded in the flame zone, as well as in the first meters above flames (Trabaud, 1989), it is logical to expect a negative effect of crown severe fires on seed survival and consequently on the post-fire density of pine seedlings. Burn severity also played a significant role in the development of pine seedlings. Thus, in the $P$. pinaster ecosystem we found that growth of regenerating seedlings was stimulated in the severely burned areas (reflected in the non-significant effect on seedling cover despite the decrease in density, as well as the increase in seedling height), but no effects were detected in the $P$. halepensis ecosystem. This difference might be explained by the differences in soil fertility (mainly P) (Pausas et al., 2003), which was enhanced by burn severity in the $P$. pinaster ecosystem we studied, but not in the $P$. halepensis ecosystem (see Fernández-García et al., 2019).

\subsection{Influence of fire frequency and severity on the competition between pines and woody understory species}

The cover of woody understory species showed an inverse relationship with the regeneration of pines, which has been explained in the literature by the competition for light, water and nutrients (De las Heras et al., 2002; Calvo et al., 2008; Arnan et al., 2013; Taboada et al., 2018). However, we observed shifts in competition in relation to the fire regime. Thus, the effects of the cover of woody understory species were relevant mostly in areas burned once, probably because this is the situation with the highest densities of both pines and shrubs, facilitating the manifestation of inter-specific competitive effects (Calvo et al., 2008). Additionally, the tallest pine seedlings in the $P$. pinaster ecosystem were found in the scenario of high severity with low cover of woody species, probably due to the high availability of resources for pine growth in these areas (Pausas et al., 2003; Fernández-García et al., 2019). In contrast, no significant effects of woody cover on $P$. halepensis height were found, but we note that in the $P$. halepensis ecosystem the cover of woody species is lower than in the $P$. pinaster ecosystem. Moreover, other factors could mask the impact of woody cover on seedling growth in the $P$. halepensis ecosystem, such as intra-specific competition (Pausas et al., 2003) or the prolonged summer drought under the Mediterranean climate regime, which could be a limiting factor in the growth of seedlings (Rodríguez-García et al., 2011; Calvo et al., 2013; Lucas-Borja, 2016).

\subsection{Consequences of combined increases in fire frequency and severity under a warming climate}

This study confirms the negative ecological consequences of a potential future regime of higher fire frequency and severity (Fernandes et al., 2008; Vázquez et al., 2015) on the post-fire regeneration of serotinous pine species in the Mediterranean Basin. Our findings indicate that two fires in 34 years combined with high severity resulted in low density and cover of pine seedlings in the $P$. pinaster $\left(0.40\right.$ seedlings $\left.\mathrm{m}^{-2}\right)$ ecosystem, and especially in the $P$. halepensis $\left(0.03\right.$ seedling $\mathrm{m}^{-2}$ ) ecosystem. The situation was aggravated if three fires occurred, decreasing the density of seedlings in the $P$. pinaster ecosystem $(\leq 0.34$ seedling $\mathrm{m}^{-2}$ ), and showing almost no seedling recruitment in the $P$. halepensis ecosystem ( 0.01 seedlings $\mathrm{m}^{-2}$ ). The seedling densities obtained in these scenarios (two wildfires with high severity, and three wildfires) in the $P$. halepensis ecosystem are below the minimum necessary for successful natural recovery of these pine forests, which has been estimated at 0.20 seedlings $\mathrm{m}^{-2}$ (2000 seedlings ha ${ }^{-1}$ ) (Rodríguez-García et al., 2011; Torres et al., 2016). Furthermore, our results indicated that the number of seedlings significantly decreased between the third and fourth year after fire, so we can expect further seedling mortality over the medium term (Daskalakou \& Thanos, 2004). Therefore, low natural regeneration after two fires plus high severity, or after three fires in a short period (34 years) may lead to low density $P$. pinaster stands and to the replacement of the $P$. halepensis forest, requiring post-fire restoration actions to preserve the pine ecosystem (Pausas et al., 2004a).

Considering that the life history traits of $P$. pinaster and $P$. halepensis are quite similar (Richardson, 2000; Tapias et al., 2004; Santana et al., 2010), the notably lower seedling recruitment after high frequencies and/or severities in Cortes de Pallás could be attributed to differences in climatic conditions, even though $P$. halepensis is adapted to drier and warmer conditions than $P$. pinaster (Richardson, 2000). The summer drought, which is two months longer in the $P$. halepensis than in the $P$. pinaster ecosystem, can limit seedling emergence and survival (Pausas et al., 2004b; Padilla \& Pugnaire, 2007; Rodríguez-García et al., 2011; Calvo et al., 2013; Lucas-Borja, 2016), potentially aggravating the impact of frequent fires. An additional aggravating factor of high fire frequencies and high severities under a dry climate is the depletion of litter and woody debris (Key, 2006; Fernández-García et al., 2018b; Taboada et al., 2018), which are key elements in reducing hydric stress in seedlings against drought (Fernández et al., 2008). Accordingly, we would expect the effects of fire frequency and burn severity to be magnified in the future in dry forested areas of the Iberian Peninsula, because of the lengthening and intensification of the summer drought projected for the Mediterranean Basin (Giorgi \& Lionello, 2008; Lucas-Borja, 2016).

\section{Conclusions}

The fire-prone forests of the Mediterranean Basin are ecosystems of particular concern considering the warmer and drier climate projected for this region, particularly during the fire season (Giorgi \& Lionello, 2008), which would lead to changes in the fire regime by increasing fire frequency and burn severity (Fernandes et al., 2008; Vázquez et al., 2015). In the present study, we demonstrated that these fire regime attributes are important drivers of the recruitment and development of $P$. 
pinaster and $P$. halepensis seedlings over the medium term after the fire (three and four years), as well as on the competition between pine seedlings and woody understory species.

Fire frequency (1978-2012) largely decreased the density, cover and height of pine seedlings in $P$. pinaster and $P$. halepensis ecosystems. The burn severity of the last wildfire reduced the density of pine seedlings in the two studied ecosystems. Pine cover was reduced mainly in the $P$. halepensis ecosystem, because the growth of Pinus pinaster was enhanced in the severely burned areas. The interactions between the cover of woody understory species and pine regeneration revealed that inter-specific competition was more noticeable in the scenarios of fire frequency and severity most favorable for seedling establishment and growth.

As a consequence of the additive impacts of both fire frequency and burn severity, the natural recovery of serotinous pines is likely to be insufficient to restore full forest cover after two wildfires in 34 years combined with high severity as well as in the areas affected by three wildfires in 34 years, particularly in a climate characterized by pronounced summer drought. This information is of considerable relevance for land managers, as it highlights the importance of minimizing the occurrence of frequent severe fires to preserve serotinous pine forests. Management strategies to reduce the risk of frequent and severe fires could be focused on breaking up fuel continuity, decreasing surface fuel accumulation, reducing canopy bulk density by selective thinning, fostering multi-species forest composition, and the enhancement of tree growth to the detriment of the shrubby understory community (Corona et al., 2014; García-Llamas et al., 2019a). The present study provides ecological clues to identify the impact of potential future fire regimes on the regeneration of serotinous pines in the Mediterranean Basin.

\section{Conflicts of interest}

The authors declare that they have no conflicts of interest.

\section{Acknowledgements}

This study was financially supported by the Spanish Ministry of Economy and Competitiveness, and the European Regional Development Fund (ERDF), in the framework of the GESFIRE (AGL2013-48189-C2-1-R) and FIRESEVES (AGL2017-86075-C2-1-R) projects; and by the Regional Government of Castile and León in the framework of the FIRECYL (LE033U14) and SEFIRECYL (LE001P17) projects. Víctor Fernández-García was supported by a predoctoral fellowship from the Spanish Ministry of Education (FPU14/00636). The analysis was carried out by the senior author during a research stay at the School of Forestry, Northern Arizona University.

\section{References}

ADCIF, 2012. Los incendios forestales en España. Decenio 2001-2010. Área de Defensa contra Incendios Forestales del Ministerio de Agricultura, Alimentación y Medio Ambiente. Available at <https://www.mapa.gob.es/es/desarrollo-rural/estadisticas/ > .

AEMET-IM, 2011. Iberian climate atlas. Air temperature and precipitation (1971-2000). Agencia Estatal de Meteorología, Ministerio de Medio Ambiente y Medio Rural y Marino. Instituto de Meteorologia de Portugal, (Eds.). Available at $<$ https://www. aemet.es/documentos/es/conocermas/publicaciones/Atlas-climatologico/Atlas. pdf $>$.

Alloza, J.M., Baeza, J., Chirino, E., Fuentes, D., García, S., Llovet, J., Ribeiro, E., Valdecantos, A., Vallejo, R., Vilagrosa, A., 2012. Informe urgente de los incendios de Andilla y Cortes de Pallás de finales de junio del 2012. Fundación Centro de Estudios Ambientales del Mediterráneo 61-93.

Arnan, X., Quevedo, L., Rodrigo, A., 2013. Forest fire occurrence increases the distribution of a scarce forest type in the Mediterranean Basin. Acta Oecol. 46, 39-47. https://doi. org/10.1016/j.actao.2012.10.005.

Baeza, M.J., Valdecantos, A., Alloza, J.A., Vallejo, J.R., 2007. Human disturbance and environmental factors as drivers of long-term post-fire regeneration patterns in Mediterranean forests. J. Veg. Sci. 18, 243-252. https://doi.org/10.1111/j.1654-1103.2007. tb02535.x.

Binkler, D., Fisher, R., 2013. Ecology and management of forest soils. Wiley-Blackwell: Chichester, UK. https://doi.org/10.1002/9781118422342.
Calvo, L., Tárrega, R., Luis, E., 1998. Space-time distribution patterns of Erica australis L. subsp. aragonensis (Willk) after experimental burning, cutting and ploughing. Plant Ecol. 137, 1-12. https://doi.org/10.1023/A:1009732722644.

Calvo, L., Tárrega, R., Luis, E., 2002. The dynamics of Mediterranean shrubs species over 12 years following perturbations. Plant Ecol. 160, 25-42. https://doi.org/10.1023/A: 1015882812563.

Calvo, L., Tárrega, R., Luis, E., 2002. Secondary succession after perturbations in a shrubland community. Acta Oecol. 23, 393-404. https://doi.org/10.1016/S1146609X(02)01164-5.

Calvo, L., Valbuena. L., Torres, O., Alvarez, R., Marcos, E., Tárrega, R., de Luis, E., 2005. Efectos de los incendios de la sierra del Teleno en la población de Pinus pinaster. In: Rey, E., Ruiz, I. (Eds.), Seminario de restauración de áreas afectadas por grandes incendios. El caso particular del Teleno. Consejería de Medio Ambiente. Junta de Castilla y León, pp. 125-137. ISBN: 84-9718-332-0.

Calvo, L., Santalla, S., Valbuena, L., Marcos, E., Tárrega, R., Luis-Calabuig, E., 2008. Postfire natural regeneration of a Pinus pinaster forest in NW Spain. Plant Ecol. 197, 81-90. https://doi.org/10.1007/s1 1258-007-9362-1.

Calvo, L., Torres, O., Valbuena, L., Luis-Calabuig, E., 2013. Recruitment and early growth of Pinus pinaster seedlings over five years after a wildfire in NW Spain. Forest Syst. 22, 582-586. https://doi.org/10.5424/fs/2013223-04623.

Corona, P., Ascoli, D., Barbati, A., Bovio, G., Colangelo, G., Elia, M., Garfi, V., Iovino, F., Lafortezza, R., Leone, V., Lovreglio, R., Marchetti, M., Marchi, E., Menguzzato, G., Nocentini, S., Picchio, R., Portoghesi, L., Puletti, L., Sanesi, G., Chianucci, F., 2014. Integrated forest management to prevent wildfires under Mediterranean environ-ments. Ann. Silvicultural Res. 38, 24-45 https://doi.org/10.12899/ASR-946.

Daskalakou, E.N., Thanos, C.A., 1996. Aleppo pine (Pinus halepensis) postfire regeneration: The role of canopy and soil seed banks. Int. J. Wildland Fire 6, 59-66. https:// doi.org/10.1071/WF9960059.

Daskalakou, E.N., Thanos, C.A., 2004. Postfire regeneration of Aleppo pine- the temporal pattern of seedling recruitment. Plant Ecol. 171, 81-89. https://doi.org/10.1023/B VEGE.0000029375.93419.f9.

De las Heras, J., Martínez-Sanchéz, J.J., González-Ochoa, A.I., Ferrandis, P., Herranz, J.M., 2002. Establishment of Pinus halepensis Mill, saplings following fire: effects of competition with shrub species. Acta Oecol. 23, 91-97. https://doi.org/10.1016/S1146609X(02)01138-4.

Doblas-Miranda, E., Alonso, R., Arnan, X., Bermejo, V., Brotons, L., De las Heras, J., Estiarte, M., Hódar, J.A., Llorens, P., Lloret, F., López-Serrano, F.R., Martínez-Vilalta, J., Moya, D., Peñuelas, J., Pino, J., Rodrigo, A., Roura-Pascual, N., Valladares, F., Vilà, M., Zamora, R., Retana, J., 2017. A review of the combination among global change factors in forests, shrublands and pastures of the Mediterranean region: beyond drought effects. Global Planet. Change 148, 42-54. https://doi.org/10.1016/j. gloplacha.2016.11.012.

Eugenio, M., Lloret, F., 2004. Fire recurrence effects on the structure and composition of Mediterranean Pinus halepensis communities in Catalonia (northeast Iberian Peninsula). Écoscience 11, 446-454. https://doi.org/10.1080/11956860.2004.11682854.

Eugenio, M., Verkaik, I., Lloret, F., Espelta, J.M., 2006. Recruitment and growth decline in Pinus halepensis populations after recurrent wildfires in Catalonia (NE Iberian Peninsula). Forest Ecol. Manage. 231, 47-54. https://doi.org/10.1080/10.1016/j.foreco. 2006.05.007.

Fernandes, P.M., Rigolot, E., 2007. The fire ecology and management of maritime pine (Pinus pinaster Ait.). Forest Ecol. Manage. 241, 1-13. https://doi.org/10.1016/j.foreco. 2007.01.010

Fernandes, P.M., Vega, J.A., Jiménez, E., Rigolot, E., 2008. Fire resistance of European pines. Forest Ecol. Manage. 256, 246-255. https://doi.org/10.1016/j.foreco.2008.04. 032 .

Fernández, C., Vega, J.A., Fonturbel, T., Jiménez, E., Pérez-Gorostiaga, P., 2008. Effects of wildfire, salvage logging and slash manipulation on Pinus pinaster Ait. recruitment in Orense (NW Spain). Forest Ecol. Manage. 255, 1294-1304. https://doi.org/10.1016/ j.foreco.2007.10.034

Fernández-García, V., Baeza, J., Santana, V.M., Tárrega, R., Valbuena, L., Taboada, A., Luis-Calabuig, E., Fernández-Guisuraga, J.M. Suárez-Seoane, S., Marcos, E., Calvo, L., 2017. ¿Son diferentes los rasgos biológicos de las plantas en relación con la severidad de incendios en pinares propensos al fuego? S.E.C.F. (Ed.), 7 Congreso Forestal Español, Gestión del monte: servicios ambientales y bioeconomía, pp. 1-10. 7CFE01-367, ISBN: 978-84-941695-2-6.

Fernández-García, V., Quintano, C., Taboada, A., Marcos, E., Calvo, L., Fernández-Manso, A., 2018. Remote sensing applied to the study of fire regime attributes and their influence on post-fire greenness recovery in pine ecosystems. Remote Sens. 10, 733. https: //doi.org/10.3390/rs10050733.

Fernández-García, V., Santamarta, M., Fernández-Manso, A., Quintano, C., Marcos, E., Calvo, L., 2018. Burn severity metrics in fire-prone pine ecosystems along a climatic gradient using Landsat imagery. Remote Sens. Environ. 206, 205-217. https://doi. org/10.1016/j.rse.2017.12.029.

Fernández-García, V., Miesel, J., Baeza, M.J., Marcos, E., Calvo, L., 2019. Wildfire effects on soil properties in fire-prone pine ecosystems: Indicators of burn severity legacy over the medium term after fire. Appl. Soil Ecol. 135, 147-156. https://doi.org/10. 1016/j.apsoil.2018.12.002.

Flatley, W.T., Fulé, P.Z., 2016. Are historical fire regimes compatible with future climate? Implications for forest restoration. Ecosphere 7e01471, https://doi.org/10.1002/ecs2. 1471.

García-Llamas, P., Suárez-Seoane, S., Taboada, A., Fernández-Manso, A., Quintano, C., Fernández-García, V., Fernández-Guisuraga, J.M., Marcos, E., Calvo, L., 2019. Environmental drivers of fire severity in extreme fire events that affect Mediterranean pine forest ecosystems. Forest Ecol. Manage. 433, 24-32. https://doi.org/10.1016/j.foreco. 2018.10 .051

García-Llamas, P., Suárez-Seoane, S., Fernández-Guisuraga, J.M., Fernández-García, V., Fernández-Manso, A., Quintano, C., Taboada, A., Marcos, E., Calvo, L., 2019b. Evaluation and comparison of Landsat 8, Sentinel-2 and Deimos-1 remote sensing indices for assessing burn severity in Mediterranean fire-prone ecosystems. Int. J. Appl. Earth Obs. (in press). 
GEODE, 2019. Mapa continuo digital de España. Instituto Geológico y Minero de España. Available at <http://mapas.igme.es/gis/services/Cartografia_Geologica/IGME_ Geode 50/MapServer/WMSServer $>$.

Giorgi, F., Lionello, P., 2008. Climate change projections for the Mediterranean region. Global Planet. Change 63, 90-104. https://doi.org/10.1016/j.gloplacha.2007.09.005.

González-De-Vega, S., De las Heras, J., Moya, D., 2016. Resilience of Mediterranean terrestrial ecosystems and fire severity in semiarid areas: responses of Aleppo pine forests in the short, mid and long term. Sci. Total Environ. 573, 1171-1177. https://doi.org/ 10.1016/j.scitotenv.2016.03.115.

Habrouk, A., Retana, J., Espelta, J.M., 1999. Role of heat tolerance and cone protection of seeds in the response of three pine species to wildfires. Plant Ecol. 154, 91-99. https: //doi.org/10.1023/A:1009851614885.

He, T., Pausas, J.G., Belcher, C.M., Schwilk, D.W., Lamont, B.B., 2012. Fire-adapted traits of Pinus arose in the fiery Cretaceous. New Phytol. 194, 751-759. https://doi.org/10. 1111/j.1469-8137.2012.04079.x.

Hernández-Serrano, A., Verdú, M., González-Martínez, S.C., Pausas, J.G., 2013. Fire structures pine serotiny at different scales. Am. J. Bot. 100, 2349-2356. https://doi.org/ 10.3732/ajb.1300182.

ICFN, 2015. Áreas ardidas por tipo de ocupação do solo (1996-2014). Instituto da Conservação da Natureza e das Florestas. Available at <http://www2.icnf.pt/portal/ florestas/dfci/inc/estat-sgif\#tip >

Jones, A., Montanarella, L., Jones, R., 2005. Soil atlas of Europe. European Comission. Available at $<$ https://esdac.jrc.ec.europa.eu/content/soil-atlas-europe $>$.

Keeley, J.E., Pausas, J.E., Rundel, P.W., Bond, W.J., Bradstock, R.A., 2011. Fire as an evolutionary pressure shaping plant traits. Trends Plant Sci. 16, 406-411. https://doi.org/ 10.1016/j.tplants.2011.04.002.

Keeley, J.E., Bond, W.J., Bradstock, R.A., Pausas, J.G., Rundel, P.W., 2012. Fire in Mediterranean Ecosystems: Ecology, Evolution and Management. Cambridge University Press, $10.1017 /$ CBO9781139033091.

Key, C.H., 2006. Ecological and sampling constraints on defining landscape fire severity. Fire Ecol. 2, 34-59. https://doi.org/10.4996/fireecology.0202034.

Lindner, M., Garcia-Gonzalo, J., Kolström, M., Geen, T., Reguera, R., Maroschek, M., Seidl, R., Lexer, M.J., Netherer, S., Schopf, A., Kremer, A., Delzon, S., Barbati, A., Marchetti, M., Corona, P., 2008. Impacts of climate change on European forests and options for adaptation. Report to the European Commission Directorate-General for Agriculture and Rural Development. AGRI-2007-G4-06. Available at < https://ec.europa.eu/ agriculture/external-studies/euro-forests_en $>$.

Lucas-Borja, E., 2016. Climate Change and Initial Seedling Recruitment in Mediterranean Forest: The Role of Seed Origin. Forest Res. 5, 1000e124. https://doi.org/10.4172/ 2168-9776.1000e124.

Maia, P., Pausas, J.G., Vasques, A., Keizer, J.J., 2012. Fire severity as a key factor in post-fire regeneration of Pinus pinaster (Ait.) in Central Portugal. Ann. Forest Sci. 69, 489-498. https://doi.org/10.1007/s13595-012-0203-6.

Moreira, F., Arianoutsou, M., Corona, P., De las Heras, J., 2012. Post-Fire Management and Restoration of Southern European Forests, Managing Forest Ecosystems. Springer Science + Business Media B.V, 10.1007/978-94-007-2208-8

Moreno, J.M., Oechel, W.C., 2012. The Role of Fire in Mediterranean-Type Ecosystems. Springer-Verlag. https://doi.org/10.1007/978-1-4613-8395-6.

Moya, D., Saracino, A., Salvatore, R., Lovreglio, R., De las Heras, J., Leone, V., 2008. Anatomic basis and insulation of serotinous cones in Pinus halepensis Mill. Trees 22, 511-519. https://doi.org/10.1007/s00468-008-0211-1.

Moya, D., González-De-Vega, S., García-Orenes, F., Morugán-Coronado, A., Arancegui, V., Mataix-Solera, Lucas-Borja, M.E., De las Heras, J., 2018. Temporal characterisation of soil-plant natural recovery related to fire severity in burned Pinus halepensis Mill. forests. Sci. Total Environ. 640-641, 42-51. https://doi.org/10.1016/j.scitotenv. 2018.05.212.

Ninyerola, M., Pons, X., Roure, J.M., 2005. Atlas climático digital de la Península Ibérica. Metodología y aplicaciones en bioclimatología y geobotánica. Universidad Autónoma de Barcelona.

Padilla, F.M., Pugnaire, F.I., 2007. Rooting depth and soil moisture control Mediterranean woody seedling survival during drought. Funct. Ecol. 21, 489-495. https://doi.org/ 10.1111/j.1365-2435.2007.01267.x

Pausas, J.G., 1999. Response of plant functional types to changes in the fire regime in Mediterranean ecosystems: A simulation approach. J. Veg. Sci. 10, 717-722. https:// doi.org/10.2307/3237086.
Pausas, J.G., Vallejo, R., 1999. The role of fire in European Mediterranean ecosystems. In: Chuvieco, E. (Ed.), Remote Sensing of Large Wildfires in the European Mediterranean Basin. Springerhttps://doi.org/10.1007/978-3-642-60164-4_2.

Pausas, J., Ouadah, N., Ferran, A., Gimeno, T., Vallejo, R., 2003. Fire severity and seedling establishment in Pinus halepensis woodlands, eastern Iberian Peninsula. Plant Ecol. 169, 205-213.

Pausas, J.G., Ribeiro, E., Vallejo, R., 2004. Post-fire regeneration variability of Pinus halepensis in the eastern Iberian Peninsula. Forest Ecol. Manage. 203, 251-259. https: //doi.org/10.1016/j.foreco.2004.07.061.

Pausas, J.G., Blade, C., Valdecantos, A., Seva, J.P., Fuentes, D., Alloza, J.A., Vilagrosa, A., Bautista, S., Cortina, J., Vallejo, R., 2004. Pines and oaks in the restoration of Mediter ranean landscapes of Spain: new perspectives for an old practice-a review. Plant Ecol. 171, 209-220. https://doi.org/10.1023/B:VEGE.0000029381.63336.20.

Pausas, J.G., Llovet, J., Rodrigo, A., Vallejo, R., 2008. Are wildfires a disaster in the Mediterranean basin? A review. Int. J. Wildland Fire 17, 713-723. https://doi.org/10. 1071/WF07151.

Pausas, J.G., Keeley, J.E., 2014. Evolutionary ecology of resprouting and seeding in fire-prone ecosystems. New Phytol. 204, 55-65. https://doi.org/10.1111/nph.12921.

Perkins, T., Adler-Golden, S., Matthew, M.W., Berk, A., Bernstein, L.S., Lee, J., Fox, M. 2012. Speed and accuracy improvements in FLAASH atmospheric correction of hyperspectral imagery. Opt. Eng. 51, 111707https://doi.org/10.1117/1.OE.51.11.111707.

Pinheiro, J., Bates, D., DebRoy, S., Sarkar, D., R Core Team, 2017. nlme: Linear and Nonlinear Mixed Effects Models. R package version 3.1-131, URL: https://CRAN.R-project. org $/$ package $=$ nlme.

R Core Team, 2017. R: A Language and Environment for Statistical Computing. R Foundation for Statistical Computing, Vienna, Austria, URL: https://www.R-project.org/.

Richardson, D.M., 2000. Ecology and Biogeography of Pinus. Cambridge University Press, Cambridge, 527.

Rodríguez-García, E., Gratzer, G., Bravo, F., 2011. Climatic variability and other site factor influences on natural regeneration of Pinus pinaster Ait. in Mediterranean forests. Ann. Forest Sci. 68, 811-823. https://doi.org/10.1007/s13595-011-0078-y.

Santana, V.M., Baeza, J., Marrs, R.H., Vallejo, V.R., 2010. Old-field secondary succession in SE Spain: can fire divert it?. Plant Ecol. 211, 337-349. https://doi.org/10.1007/ sll258-010-9793-y.

Taboada, A., Tárrega, R., Marcos, E., Valbuena, L., Suárez-Seoane, S., Calvo, L., 2017. Fire recurrence and emergency post-fire management influence seedling recruitment and growth by altering plant interactions in fire-prone ecosystems. Forest Ecol. Manage. 402, 63-75. https://doi.org/10.1016/j.foreco.2017.07.029.

Taboada, A., Fernández-García, V., Marcos, E., Calvo, L., 2018. Interactions between large high-severity fires and salvage logging on a short return interval reduce the regrowth of fire-prone serotinous forests. Forest Ecol. Manage. 414, 54-63. https://doi.org/10. 1016/j.foreco.2018.02.013.

Tapias, R., Gil, L., Fuentes-Utrilla, P., Pardos, J.A., 2001. Canopy seed banks in Mediterranean pines of southeastern Spain: a comparison between Pinus halepensis Mill., Pinus pinaster Ait., Pinus nigra Arn. and Pinus pinea L. J. Ecol. 89, 629-638. https:// doi.org/10.1046/j.1365-2745.2001.00575.x.

Tapias, R., Climent, J., Pardos, J.A., Gil, L., 2004. Life histories of Mediterranean pines. Plant Ecol. 171, 53-68. https://doi.org/10.1023/B:VEGE.0000029383.72609.f0.

Teillet, P.M., Guindon, B., Goodenough, D.G., 1982. On the slope-aspect correction of multispectral scanner data. Can. J. Remote. Sens. 8, 84-106. https://doi.org/10.1080/ 07038992.1982.10855028.

Torres, I., Pérez, B., Quesada, J., Viedma, O., Moreno, J.M., 2016. Forest shifts induced by fire and management legacies in a Pinus pinaster woodland. Forest Ecol. Manage. 361, 309-1217. https://doi.org/10.1016/j.foreco.2015.11.027.

Trabaud, L., 1989. Les feux des forêts. France-Selection, Aubervilliers, France.

Vázquez, A., Climent, J.M., Casais, L., Quintana, J.R., 2015. Current and future estimates for the fire frequency and the fire rotation period in the main woodland types of peninsular Spain: a case-study approach. Forest Syst. 24, e031https://doi.org/10. 5424/fs/2015242-06454

Vega, J.A., Fernández, C., Pérez-Gorostiaga, P., Fonturbel, T., 2008. The influence of fire severity, serotiny, and post-fire management on Pinus pinaster Ait. recruitment in three burnt areas in Galicia (NW Spain). Forest Ecol. Manage. 256, 1596-1603. https: //doi.org/10.1016/j.foreco.2008.07.005

Venables, W.N., Ripley, B.D., 2002. Modern Applied Statistics with S, fourth ed. Springer, New York. 